\title{
BIM-enabled Sustainability Assessment of Design for Manufacture and Assembly
}

\author{
Tan Tan ${ }^{\mathrm{a}}$, Eleni Papadonikolaki ${ }^{\mathrm{a}}$, Grant Mills ${ }^{\mathrm{a}}$, Junfei Chen ${ }^{\mathrm{b}}$, Zhe Zhang ${ }^{\mathrm{c}}$, Ke Chen $^{\mathrm{d}}$ \\ ${ }^{a}$ The Bartlett School of Sustainable Construction, University College London, United Kindom \\ ${ }^{b}$ Wuhan Zhenghua Architectural Design Co., LTD, China \\ ${ }^{c}$ School of Property, Construction and Project Management, Royal Melbourne Institute of Technology, Australia \\ ${ }^{d}$ Department of Construction Management, Huazhong University of Science and Technology, China
}

E-mail: tan.tan.17@ucl.ac.uk, e.papadonikolaki@ucl.ac.uk, g.mills@ucl.ac.uk, chenjunfei@zhdi.net, S3705625@student.rmit.edu.au, chenkecm@hust.edu.cn

\begin{abstract}
-
Design for Manufacture and Assembly (DfMA) is an emerging concept introduced from the manufacturing sector to transform the construction industry and accelerating "off-site" capabilities. Enhancing the sustainability of DfMA is challenging and requires accounting for various environmental and managerial impacts on the process of manufacture and assembly, especially for the parametric buildings with irregular shapes and unstandardised components. It is essential to compare and make decisions among design alternatives for the best-fit sustainability in the DfMA process. However, there is presently a gap in the DfMA field. This paper proposed a novel BIM-enabled Multi-Criteria Decision Making (MCDM) method for the sustainability assessment of parametric façade design. An under-construction parametric building was used to test and illustrate the method. A parametric façade was selected to demonstrate the application of DfMA to enable mass "off-site" customisation. This is a labour-intensive assembly process, which could significantly benefit from the implementation of such a method. Data collection involves archival data and semi-structured interviews. An integrated fuzzy AHP-TOPSIS was used to analysis the data. This research sheds new lights on DfMA sustainability and its decision support systems. Unlike the usual attention to the construction sustainability of on-site construction, the method involves consideration of both manufacture and assembly stages. It provides practitioners with a decision-making method to select the most sustainable façade alternative available for the parametric design. The findings carry implications for parametric façade design and show the deployment of mass customised unstandardised components. This research opens up new avenues for sustainable DfMA development.
\end{abstract}

Keywords -

DfMA; Parametric design; BIM; Decision making; Sustainability

\section{Introduction}

The harsh environmental impact of the building production process makes sustainable design and construction urgently important [1,2]. A key part of the "off-site revolution" must be the consideration of how we can enhance sustainability in design. This requires the integration of sustainability factors and knowledge in different building phases (such as manufacturing, assembly, and operation and maintenance) [3,4]. However, unlike conventional construction methods, offsite constructuion requires the evaluation of sustainability in the design stage [5,6]. The United Kingdom(UK), Singapore, and Hong Kong governments have identified Design for Manufacture and Assembly (DfMA) as the way to accelerate the efficiency and sustainability of the construction industry $[4,7,8]$. Although, little is known about how DfMA relates to sustainability research. One of the primary challenges is to compare and make decisions among design alternatives for the best-fit sustainability in the DfMA process.

Decisions are judgments based on information, and poor-quality information inevitably results in poor decision-making [9]. Building Information Modeling (BIM), as an innovative digital technology, is expected to evolve the traditional form of information management [10] and enhance the ability of construction sustainability [11,12]. Horizontal integration between various stakeholders and vertical integration of information at different stages becomes possible with the incentive of BIM [13]. In the early design phase of projects, designers can identify better solutions based on integrated information and various functions from BIM 
[14].

Multi-Criteria Decision Making (MCDM) is a basic approach in decision-making procedure which models decision problems by processing various information $[15,16]$. These decision problems are described by the presence of various decision criteria which could be quantifiable or nonquantifiable [17]. In the Architectural Engineering and Construction (AEC) industry, MCDM has also demonstrated its powerful auxiliary capabilities in decision-making. The potential ability of MCDM in the AEC industry can be better stimulated with the cooperation of BIM [18]. Vice versa, BIM capabilities will also be promoted by MCDM which helps to overcome limitations of BIM related to optimising multiobjectives while still exploiting its benefit [19].

This study aims to establish a BIM-enabled MCDM method that incorporates sustainable assessment. BIM was used in the design optimisation and data collection process. Fuzzy theory, Analytic Hierarchy Process (AHP) and Technique for Order Preference by Similarity to an Ideal Solution (TOPSIS) were combined for the integrated MCDM. An empirical design case with three design alternatives for its parametric façade system was used in this study. A focus on a parametric façade was selected as the case as it provides an example of mass "off-site" customisation and a labour-intensive assembly process. Data collection involved the use of archival data, a series of interviews and questionnaires. In summary, this research contributes a sustainable design evaluation method to the field of DfMA.

\section{Literature Review}

\subsection{Design for Manufacture and Assembly}

Boothroyd [20] defines DfMA as a methodology to evaluate and improve product design by considering the downstream manufacturing and assembly processes, which signifies a shift from a traditional, sequential design process to a non-linear methodology. This emerging concept has been widely used in the manufacturing industry and then introduced into the AEC industry by the UK, Singapore, Hong Kong governments in recent years $[4,8]$. Gao, et al. [21] defines DfMA as 1) design strategy; 2) design evaluation method; and 3) design philosophy. Implementing Design for Manufacture (DfM) and Design for Assembly (DfA) can bring considerable benefits for construction sustainability by simplifying and optimising design and then shortening the construction process. DfMA is thus regarded as a circular economy solution for sustainable development [22]. To move forward the development of DfMA, further research can be conducted to establish related sustainability evaluation methods and strategies.

\subsection{Sustainability Assessment}

Sustainability assessment focuses on realising positive net sustainability benefits now and in the future. It is the process that leads decision-makers to sustainability $[23,24]$. The concept of sustainable building usually considers the whole life-cycle performance of sustainability, including social, economic, cultural, and environmental characteristics [25]. Rodríguez López and Fernández Sánchez [26] illustrated the challenges of sustainability assessment in the AEC industry. The spreading of prefabrication and DfMA has been changing the weight importance of different lifecycle building stages. The design process is also changed. Cross-disciplines collaboration and more detailed design would be involved in the early design stage, which raises challenges to traditional construction sustainability assessment. The emerging activities, including off-site manufacturing and on-site assembly, create new opportunities and application scenarios for sustainable design optimisation when compared with conventional on-site construction. Architects and engineers can optimise the design alternative by considering the sustainability performance in the manufacture and assembly stages. Innovation is required, to create a holistic tool for the sustainability assessment. This has been highlighted by both the policy-makers and the scientific community [27]. The authors now consider the development of such a technique.

\subsection{BIM-enabled MCDM}

Sustainability can be considered as a MCDM problem [28,29]. BIM-enabled MCDM is emerging as a trend in the AEC industry. In addition, there are many sustainability assessment studies at both the building and component level. Yet very little is known about their relationship [30]. Chen and Pan [18] proposed a method for low carbon building measures selection. Mahmoud, et al. [31] developed a global sustainability rating technique for existing buildings. Jalilzadehazhari, et al. [19] used MCDM-enabled BIM to take account of building energy requirements while simultaneously improving indoor environment quality. In the component level, Marzouk and Abdelakder [32] used BIM-enabled MCDM to identify sustainable materials. Jalaei, et al. [33], Khanzadi, et al. [34] and Fazeli, et al. [17] developed tools to select optimal sustainable components. $\mathrm{Yu}$ and Woo [35] proposed a model for buildingenvelope structural modification system for energy efficiency. Juszczyk and Zima [36] enhanced the green façade by MCDM. It can be observed that the integration of BIM and MCDM has been profusely applied in sustainability-related issues in the AEC industry [30]. However, there is no research about BIM-enabled MCDM for sustainability assessment in the DfMA 
process. A method to allow the consideration of sustainability performance during both the manufacture and assembly stages is however urgently needed.

\section{The Proposed Framework}

\subsection{Criteria System for Sustainability Assessment of DfMA}

Various multi-criteria were carefully obtained by considering the literature review and expert opinions. One of the authors dominated the design of three alternatives and worked closely with all other disciplines, manufacturers and contractors. Further data were collected by other authors who conducted a series of informal interviews with the designers, documentations and related articles.

As shown in Table 1, four dimensions can be used to structure DfMA sustainability assessment, including manufacture, assembly, operation and maintenance. Overall 11 criteria are identified. They were derived from the construction-oriented DfMA guidelines [4].

Table 1 Criteria System for Sustainability Assessment of DfMA

\begin{tabular}{|c|c|}
\hline $\begin{array}{l}\text { L2 } \\
\text { Dimension }\end{array}$ & L3 Multi-Criteria \\
\hline \multirow{2}{*}{ Manufacture } & A1 Reduced number of molds \\
\hline & A2 Reduced number of part counts \\
\hline \multirow[t]{3}{*}{ Assembly } & $\begin{array}{l}\text { A3 Reduced and standardised } \\
\text { number and type of connectors }\end{array}$ \\
\hline & A4 Assembly error tolerance \\
\hline & $\begin{array}{l}\text { A5 lightened material and } \\
\text { components }\end{array}$ \\
\hline \multirow[t]{4}{*}{ Operation } & $\begin{array}{l}\text { A6 Environmentally friendly } \\
\text { materials }\end{array}$ \\
\hline & $\begin{array}{lll}\text { A7 Low operation } & \text { energy } \\
\text { consumption } & & \end{array}$ \\
\hline & $\begin{array}{l}\text { A8 Environmentally friendly } \\
\text { building forms }\end{array}$ \\
\hline & $\begin{array}{l}\text { A9 Environmentally friendly indoor } \\
\text { space }\end{array}$ \\
\hline \multirow{2}{*}{ Maintenance } & A10 Reduced fragile parts \\
\hline & $\begin{array}{l}\text { A11 Easy replacement of building } \\
\text { components and materials }\end{array}$ \\
\hline
\end{tabular}

\subsection{Fuzzy AHP Method}

The aim of this analysis is to compare different criteria to optimise and determine the most appropriate sustainable design based on BIM platform. Combining MCDM methods with BIM has been systematically analysised in previous study [30]. AHP is a widely used method with MCDM to facilitate the selection among various alternatives. The AHP method has been used to weight each criterion by decision makers or experts, and then to generate priorities by constructing a hierarchy. The FAHP methodology has further developed the conventional AHP method by integrating fuzzy set theory to analyse uncertain judgment of experts, such as using natural language.

The concise steps of the Fuzzy AHP Method are as follows:

Step 1. Define linguistic scale of relative importance used in the pairwise comparison matrix

In practice, the Triangular Fuzzy Number (TFN) scale from 1 to 9 , is commonly used to structure a comparison matrix. And the TFNs are defined with the membership function referred to the research Metin Celik (Table 2):

Table 2 Scale of Relative Importance

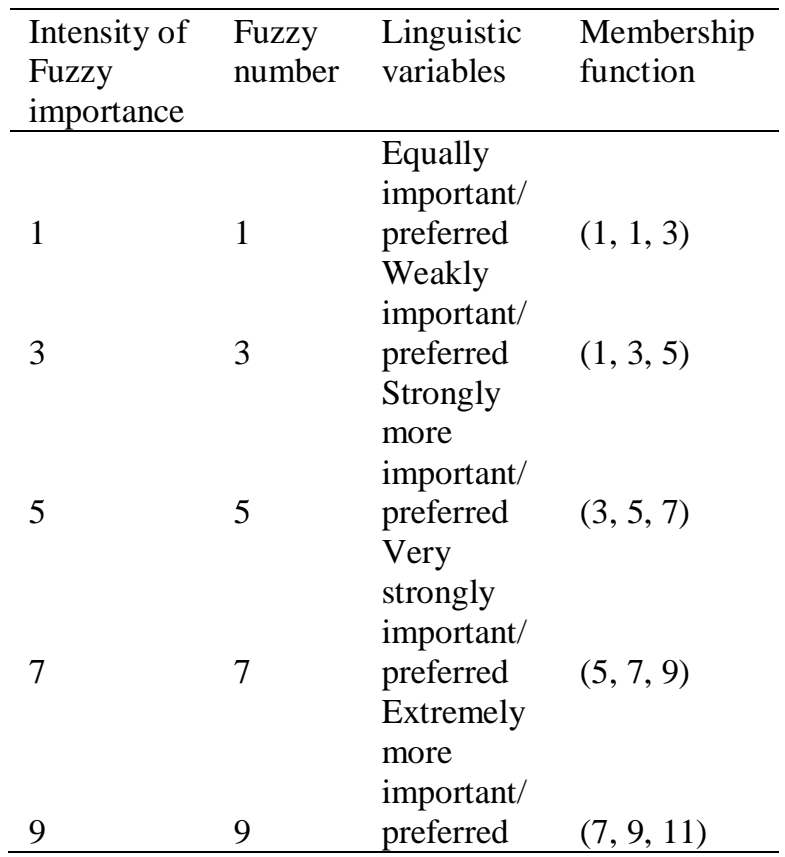

Step 2. Construct a fuzzy comparison matrix

The experts are given a questionnaire to make a pairwise comparison weight for criteria. The fuzzy comparison matrix is calculated by the Equation (1) 


$$
A=\left[\begin{array}{cccc}
1 & \tilde{\mathrm{a}}_{12} & \cdots & \tilde{\mathrm{a}}_{1 \mathrm{n}} \\
\tilde{\mathrm{a}}_{21} & 1 & \cdots & \tilde{\mathrm{a}}_{2 \mathrm{n}} \\
\vdots & \vdots & \vdots & \vdots \\
\tilde{\mathrm{a}}_{\mathrm{n} 1} & \tilde{\mathrm{a}}_{\mathrm{n} 2} & \cdots & 1
\end{array}\right]
$$

Step 3. Check consistency of the matrix

In order to balance the results of the method, it is necessary to calculate the consistency ratio (CR) for each of the matrix and overall hierarchy. The consistency check process is as follows.

i) Calculate the largest Eigen value of the comparison matrix.

$$
A w=\lambda_{\max } w
$$

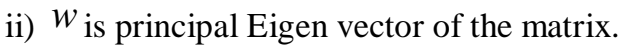

Calculate the consistency ratio.

$$
\begin{gathered}
C R=\frac{C I}{R I} \\
C I=\frac{\lambda_{\max }-n}{n-1}
\end{gathered}
$$

$\mathrm{RI}$ is random index (Table 2). CI is consistency index and $\mathrm{n}$ is matrix size.

Table 3 The Random Index RI

\begin{tabular}{lllllllll}
\hline $\begin{array}{l}\text { Size } \\
(\mathrm{n})\end{array}$ & 1 & 2 & 3 & 4 & 5 & 6 & 7 & 8 \\
\hline & 0.0 & 0.0 & 0.5 & 0.8 & 1.1 & 1.2 & 1.3 & 1.4 \\
RI & 0 & 0 & 2 & 9 & 1 & 5 & 5 & 0 \\
\hline
\end{tabular}

The consistency ratio should followed the rule that only if the $\mathrm{CR} \leq 0.10$ is acceptable.

Step 4. Compute the weight of each criterion

\subsection{TOPSIS Method}

TOPSIS is one of the useful MCDM methods and can be combined with AHP. According to this technique, the best alternative would be the one that is nearest to the positive ideal solution and farthest from the negative ideal solution. The positive ideal solution is a solution that maximises the benefit criteria and minimises the cost criteria, whereas the negative ideal solution maximises the cost criteria and minimises the benefit criteria. In this study, TOPSIS method is used for determining the final ranking of the façade design. The method is calculated as follows:

Step 1. Decision matrix is normalised:

$$
\begin{gathered}
r_{i j}=\frac{w_{i j}}{\sqrt{\sum_{j=1}^{J} w_{i j}^{2}}} \quad j=1,2,3, \ldots, J \quad i \\
=1,2,3, \ldots, n
\end{gathered}
$$

Step 2. Weighted normalised decision matrix is formed:

$$
v_{i j}=w_{i j} * r_{i j}, j=1,2,3, \ldots, J, i=1,2,3, \ldots, n
$$

Step 3. Positive ideal solution (PIS) and negative ideal solution (NIS) are determined:

$$
\begin{aligned}
A^{*} & =\left\{v_{1}^{*}, v_{2}^{*}, \ldots, v_{n}^{*},\right\} \text { Maximum values } \\
A^{-} & =\left\{v_{1}^{-}, v_{2}^{-}, \ldots, v_{n}^{-},\right\} \text {Minimum values }
\end{aligned}
$$

Step 4. The distance of each alternative from PIS and NIS are calculated:

$$
\begin{aligned}
& d_{i}^{*}=\sqrt{\sum_{j=1}^{n}\left(v_{i j}-v_{j}^{*}\right)^{2}}, j=1,2, \ldots, J \\
& d_{i}^{-}=\sqrt{\sum_{j=1}^{n}\left(v_{i j}-v_{j}^{-}\right)^{2}, i}=1,2, \ldots, J
\end{aligned}
$$

Step 5. The closeness coefficient of each alternative is calculated:

$$
C C_{i}=\frac{d_{i}^{-}}{d_{i}^{*}+d_{i}^{-}}, i=1,2, \ldots, J
$$

Step 6. By comparing $\mathrm{CCi}$ values, the ranking of alternatives is determined.

\section{Case Study}

\subsection{Context and Background}

The case is a façade renovation project located in Wuhan, China. One of the authors took the lead for the architectural design. Three alternatives were selected for the sustainability assessment, as shown in Figure 1, 2, and 3. BIM models were used for data collection and analysis. The façade system was manufactured off-site and assembled on site. The parameterised special-shaped façade in some design schemes has brought great challenges to manufacturing and assembly, especially in terms of sustainability assessment. 


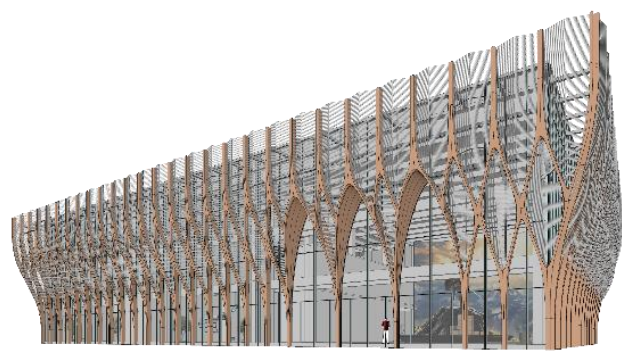

Figure 1 Alternative façade design A

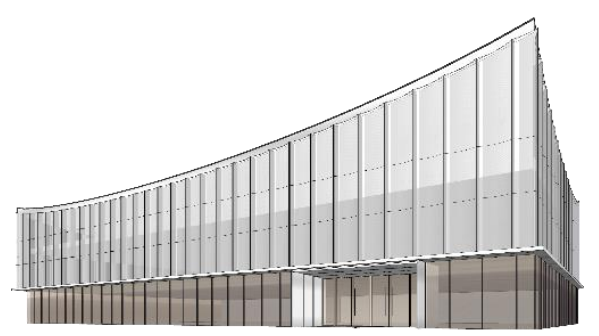

Figure 2 Alternative façade design B

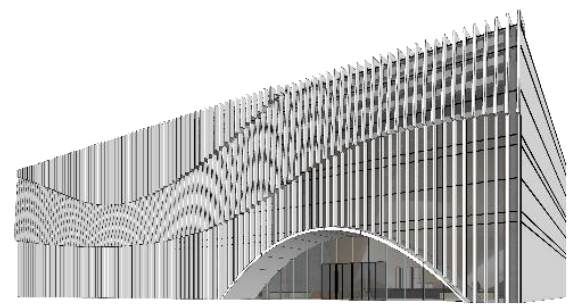

Figure 3 Alternative façade design $\mathrm{C}$

\subsection{Case Study results}

By applying the proposed computational framework to the case study, the several steps below were generated to explore the best solution among design alternatives.

Step 1. Fuzzy AHP to calculate the weight

The experts made pairwise comparisons of 4 dimensions and 11 criteria to construct a fuzzy comparison matrix by using linguistic scale Table 2 . FAHP then calculated the matrix weight. The results of the weight calculation are given in Table 4 and Table 5. The Consistency Ratio (CR) value of all matrixes was tested at less than 0.1 . Thus, these results are acceptable. And Table 5 reveals the ranking of the 11 criteria.

Table 4 Weight of the 4 dimensions and the CR value

\begin{tabular}{lll}
\hline Dimension & WeightCR \\
\hline Manufacture 0.2833 & \\
Assembly & 0.2 & \\
Operation & 0.35 & 0.0313 \\
Maintenance 0.1667 & \\
\hline
\end{tabular}

Table 5 Weight of the multi-criteria and the ranking

\begin{tabular}{|c|c|c|c|c|c|}
\hline Dimension & Criteria & $\begin{array}{l}\text { Criterio } \\
\mathrm{n} \\
\text { weight }\end{array}$ & $\begin{array}{l}\text { Ratio } \\
\text { weigh } \\
\mathrm{t}\end{array}$ & $\begin{array}{l}\text { Ran } \\
\mathrm{k}\end{array}$ & CR \\
\hline \multirow[t]{2}{*}{$\begin{array}{l}\text { Manufactur } \\
\text { e }\end{array}$} & $\begin{array}{l}\text { Reduced } \\
\text { number of } \\
\text { molds }\end{array}$ & 0.2267 & 0.8 & 1 & . \\
\hline & $\begin{array}{l}\text { Reduced } \\
\text { number of part } \\
\text { counts }\end{array}$ & 0.0567 & 0.2 & 9 & 0 \\
\hline \multirow[t]{3}{*}{ Assembly } & $\begin{array}{l}\text { Reduced and } \\
\text { standardized } \\
\text { number and } \\
\text { type of } \\
\text { connectors }\end{array}$ & 0.0667 & $\begin{array}{l}0.333 \\
3\end{array}$ & 8 & 0.022 \\
\hline & $\begin{array}{l}\text { Assembly error } \\
\text { tolerance }\end{array}$ & 0.0333 & $\begin{array}{l}0.166 \\
7\end{array}$ & 11 & 2 \\
\hline & $\begin{array}{l}\text { Lightened } \\
\text { material and } \\
\text { components }\end{array}$ & 0.1 & 0.5 & 4 & \\
\hline \multirow[t]{4}{*}{ Operation } & $\begin{array}{l}\text { Environmentall } \\
\text { y friendly } \\
\text { materials }\end{array}$ & 0.09 & $\begin{array}{l}0.257 \\
1\end{array}$ & 5 & \\
\hline & $\begin{array}{l}\text { Low operation } \\
\text { energy } \\
\text { consumption }\end{array}$ & 0.1198 & $\begin{array}{l}0.342 \\
3\end{array}$ & 2 & 0.097 \\
\hline & $\begin{array}{l}\text { Environmentall } \\
\text { y friendly } \\
\text { building forms }\end{array}$ & 0.0731 & $\begin{array}{l}0.208 \\
7\end{array}$ & 6 & 5 \\
\hline & $\begin{array}{l}\text { Environmentall } \\
\text { y friendly } \\
\text { indoor space }\end{array}$ & 0.0672 & $\begin{array}{l}0.191 \\
9\end{array}$ & 7 & \\
\hline \multirow[t]{2}{*}{$\begin{array}{l}\text { Maintenanc } \\
\text { e }\end{array}$} & $\begin{array}{l}\text { Reduced fragile } \\
\text { parts }\end{array}$ & 0.1167 & 0.7 & 3 & \\
\hline & $\begin{array}{l}\text { Easy } \\
\text { replacement of } \\
\text { building } \\
\text { components } \\
\text { and materials }\end{array}$ & 0.05 & 0.3 & 10 & 0 \\
\hline
\end{tabular}

Step 3. TOPSIS to evaluate the priority of alternatives

In this stage, the TOPSIS procedure commenced from calculating the weight of each criterion of the decision matrix according to the FAHP analysis result and experts survey which showed in Table 6. Then, the method determined the positive ideal and negative ideal solutions presented in Table 7. After that, the relative closeness of each design alternative to the ideal solution was calculated separately. The final result of TOPSIS is shown in Table 8 which reveals the facade Design 3 is the highest rank solution. 
Table 6 The weight of each criterion

\begin{tabular}{llllllllllllll}
\hline $\begin{array}{l}\text { Criter } \\
\text { ion }\end{array}$ & A1 & A2 & A3 & A4 & $\begin{array}{l}\text { A } \\
5\end{array}$ & A6 A7 & A8 & A9 & A10 & $\begin{array}{l}\text { A1 } \\
1\end{array}$ \\
\hline P1 & 0.68 & 0.17 & 0.40 & 0.09 & 0. & 0.20 .47 & 0.36 & 0.3 & 0.93 & 0. \\
& 01 & 01 & 02 & 99 & 7 & 7 & 92 & 55 & 36 & 36 & 4 \\
P2 & 1.13 & 0.22 & 0.46 & 0.26 & 0. & 0.20 .83 & 0.51 & 0.3 & 0.81 & 0. \\
& 35 & 68 & 69 & 64 & 8 & 7 & 86 & 17 & 36 & 69 & 3 \\
P3 & 1.81 & 0.45 & 0.53 & 0.19 & 0.0 .2 & 0.71 & 0.43 & 0.3 & 0.70 & 0. \\
& 36 & 36 & 36 & 98 & 8 & 7 & 88 & 86 & 36 & 02 & 3 \\
\hline
\end{tabular}

Table 7 The positive ideal and negative ideal solutions

\begin{tabular}{lll}
\hline Criterion & $\begin{array}{l}\text { Negative ideal } \\
\text { solution }\end{array}$ & $\begin{array}{l}\text { Positive Ideal } \\
\text { solution }\end{array}$
\end{tabular}

Reduced number of molds

Reduced number of part

$8.19036 \mathrm{E}-05 \quad 0.928459741$ counts

Reduced and $0.000345743 \quad 0.98052739$ standardised number and type of connectors

Assembly error tolerance

$0.000514647 \quad 0.857401979$

Lightened material and components

Environmentally friendly materials

Low operation energy consumption

Environmentally friendly building forms

Environmentally friendly indoor space

Reduced fragile parts

$0.000383019 \quad 0.894350508$

Easy replacement of building components and materials

Table 8 The final ranking result of TOPSIS

\begin{tabular}{lllll}
\hline Design & $\begin{array}{l}\text { Positive } \\
\text { ideal } \\
\text { separation }\end{array}$ & $\begin{array}{l}\text { Negative } \\
\text { ideal } \\
\text { separation }\end{array}$ & $\begin{array}{l}\text { Relative } \\
\text { closeness }\end{array}$ & $\begin{array}{l}\text { Rankin } \\
\mathrm{g}\end{array}$ \\
\hline Facade & 2.31192823 & 1.34058900 & 0.36703153 & 3 \\
1 & 7 & 3 & 3 &
\end{tabular}

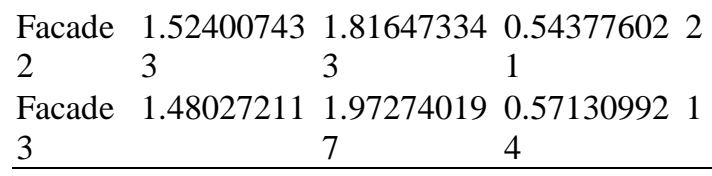

\section{Discussions and Conclusions}

Conventional 2D drawings cannot accurately deliver the information of complex buildings, which brings great difficulties to sustainable assessment and design optimisation. The optimisation result may be inconsistent with the architectural design and lead to high manufacture or assembly cost. At the same time, it may have a serious impact on construction sustainability. BIM has the opportunity to overcome this difficulty and facilitate decision-making in the DfMA process.

The facade design optimisation is critical to the fabrication of complex building shapes. The division of the façade system is not only limited by the technical requirements of the façade system itself, but also has an impact on structural design, and even affects the later mechanical and electrical installation. This requires that in the early stage of design optimisation, the construction team not only needs to coordinate various disciplines and understand the constraints of facade optimisation. There is also a need to determine the expected results of facade optimisation from the perspective of sustainability.

This study proposed a decision-making method to incorporate sustainability assessment into the DfMA process by comparing among design alternatives. The multi-criteria for sustainability assessment consists of four dimensions, including manufacture, assembly, operation and maintenance. Totally, eleven criteria were used to establish the FAHP-TOPSIS method, including reduced number of molds, reduced number of part counts, reduced and standardised number and type of connectors, assembly error tolerance, lightened material and components, environmentally friendly materials, low operation energy consumption, environmentally friendly building forms, environmentally friendly indoor space, reduced fragile parts, easy replacement of building components and materials. The computational method adopted an under-construction case with three façade alternatives.

This research contributes to the field of DfMA by providing a new approach to BIM-enabled MCDM, and sustainability assessment. It supports the design evaluation of DfMA by establishing a BIM-enabled MCDM method. Practitioners can use this method to evaluate the sustainability of the design of prefabricated buildings, thereby optimising the concept design and split design. The findings carry implications for parametric façade design and support the deployment of the mass customisation of unstandardised components. However, the case has a relatively low level application of BIM, 
and BIM models were only used for data collection and evaluation. Future research is needed to collect data on case types and multi-criteria decision making to validate the application and expanded use of such methods.

\section{Acknowledgement}

This study is supported by Major Scientific and Technological Innovation Project in Hubei Province (2020ACA006).

\section{References}

[1] G.K. Ding, Sustainable construction-The role of environmental assessment tools, Journal of Environmental Management 86 (3) (2008), pp. 451-464.

[2] C.J. Kibert, Sustainable construction: green building design and delivery, John Wiley \& Sons, 2016.

[3] M. Wasim, P. Vaz Serra, T.D. Ngo, Design for manufacturing and assembly for sustainable, quick and cost-effective prefabricated construction-a review, International Journal of Construction Management (2020), pp. 1-9.

[4] T. Tan, W. Lu, G. Tan, F. Xue, K. Chen, J. Xu, J. Wang, S. Gao, Construction-Oriented Design for Manufacture and Assembly (DfMA) Guidelines, Journal of Construction Engineering Management (2020).

[5] M. Sandanayake, W. Luo, G. Zhang, Direct and indirect impact assessment in off-site construction-A case study in China, Sustainable Cities and Society 48 (2019), p. 101520.

[6] X. Hu, H.-Y. Chong, Environmental sustainability of off-site manufacturing: a literature review, Engineering Construction and Architectural Management (2019).

[7] T. Tan, G. Mills, E. Papadonikolaki, W. Lu, K. Chen, BIM-enabled Design for Manufacture and Assembly, 27th International Workshop on Intelligent Computing In Engineering, Berlin University Press, Berlin, Germany, 2020.

[8] W. Lu, T. Tan, J. Xu, J. Wang, K. Chen, S. Gao, F. Xue, Design for manufacture and assembly (DfMA) in construction: the old and the new, Architectural Engineering and Design Management (2021), pp. 1-17.

[9] S. Elonen, K.A. Artto, Problems in managing internal development projects in multi-project environments, International Journal of Project Management 21 (6) (2003), pp. 395-402.

[10] C.M. Eastman, C. Eastman, P. Teicholz, R. Sacks, K. Liston, BIM handbook: A guide to building information modeling for owners, managers, designers, engineers and contractors, John Wiley \& Sons, 2011.

[11] J.K.W. Wong, J. Zhou, Enhancing environmental sustainability over building life cycles through green BIM: A review, Automation in Construction 57 (2015), pp. 156165.

[12] S. Azhar, J. Brown, R. Farooqui, BIM-based sustainability analysis: An evaluation of building performance analysis software, Proceedings of the 45th ASC annual conference, Vol. 1, Citeseer, 2009, pp. 276-292.

[13] Y.-F. Chang, S.-G. Shih, BIM-based computeraided architectural design, Computer-Aided Design and Applications 10 (1) (2013), pp. $97-$ 109.

[14] B. Ilhan, H. Yaman, Green building assessment tool (GBAT) for integrated BIM-based design decisions, Automation in Construction 70 (2016), pp. 26-37.

[15] E. Kazimieras Zavadskas, J. Antucheviciene, H. Adeli, Z. Turskis, Hybrid multiple criteria decision making methods: A review of applications in engineering, Scientia Iranica 23 (1) (2016), pp. 1-20.

[16] J. Antucheviciene, E.K. Zavadskas, Modelling multidimensional redevelopment of derelict buildings, International Journal of Environment Pollution 35 (2-4) (2008), pp. 331-344.

[17] A. Fazeli, F. Jalaei, M. Khanzadi, S. Banihashemi, BIM-integrated TOPSIS-Fuzzy framework to optimise selection of sustainable building components, International Journal of Construction Management (2019), pp. 1-20.

[18] L. Chen, W. Pan, BIM-aided variable fuzzy multi-criteria decision making of low-carbon building measures selection, Sustainable Cities and Society 27 (2016), pp. 222-232.

[19] E. Jalilzadehazhari, A. Vadiee, P. Johansson, Achieving a trade-off construction solution using BIM, an optimisation algorithm, and a multi-criteria decision-making method, Buildings 9 (4) (2019), pp. 1-14, Article 81.

[20] G. Boothroyd, Assembly automation and product design, CRC Press, 2005.

[21] S. Gao, R. Jin, W. Lu, Design for manufacture and assembly in construction: a review, Building Research \& Information 48 (5) (2020), pp. 538-550.

[22] B. Sanchez, C. Haas, Capital project planning for a circular economy, Construction Management and Economics 36 (6) (2018), pp. 303-312. 
[23] A.J. Bond, A. Morrison-Saunders, Reevaluating sustainability assessment: aligning the vision and the practice, Environmental Impact Assessment Review 31 (1) (2011), pp. 17.

[24] T. Hacking, P. Guthrie, A framework for clarifying the meaning of Triple Bottom-Line, Integrated, and Sustainability Assessment, Environmental Impact Assessment Review 28 (2-3) (2008), pp. 73-89.

[25] L. Bragança, R. Mateus, H. Koukkari, Building sustainability assessment, Sustainability (Switzerland) 2 (7) (2010).

[26] F. Rodríguez López, G. Fernández Sánchez, Challenges for sustainability assessment by indicators, Leadership and Management in Engineering 11 (4) (2011), pp. 321-325.

[27] A. Kylili, P.A. Fokaides, Policy trends for the sustainability assessment of construction materials: A review, Sustainable Cities and Society 35 (2017), pp. 280-288.

[28] L. Diaz-Balteiro, J. González-Pachón, C. Romero, Measuring systems sustainability with multi-criteria methods: A critical review, European Journal of Operational Research 258 (2) (2017), pp. 607-616.

[29] L. Janeiro, M.K. Patel, Choosing sustainable technologies. Implications of the underlying sustainability paradigm in the decision-making process, Journal of Cleaner Production 105 (2015), pp. 438-446.

[30] T. Tan, M. Grant, P. Eleni, L. Zhening, Combining multi-criteria decision making (MCDM) methods with building information modelling (BIM): A review, Automation in Construction 121 (2021), Article 103451.

[31] S. Mahmoud, T. Zayed, M. Fahmy, Development of sustainability assessment tool for existing buildings, Sustainable Cities and Society 44 (2019), pp. 99-119.

[32] M. Marzouk, M. Abdelakder, A hybrid fuzzyoptimisation method for modeling construction emissions, Decision Science Letters 9 (1) (2020), pp. 1-20.

[33] F. Jalaei, A. Jrade, M. Nassiri, Integrating decision support system (DSS) and building information modeling (BIM) to optimise the selection of sustainable building components, Journal of Information Technology in Construction 20 (2015), pp. 399-420.

[34] M. Khanzadi, A. Kaveh, M.R. Moghaddam, S.M. Pourbagheri, Optimisation of building components with sustainability aspects in BIM environment, Periodica Polytechnica Civil Engineering 63 (1) (2019), pp. 93-103.
[35] Y. Yu, S.J. Woo, A study on the model of a building-envelope structural modification system to increase energy efficiency at the schematic design stage, Journal of Asian Architecture and Building Engineering 12 (2) (2013), pp. 189-196.

[36] M. Juszczyk, K. Zima, Analysis of the possibility of selecting green facades in the decision making process, International Multidisciplinary Scientific GeoConference Surveying Geology and Mining Ecology Management, SGEM, Vol. 18, International Multidisciplinary Scientific Geoconference, 2018, pp. 59-66. 